\title{
Communication Skills: Top Priority of Teaching Competency
}

\author{
Mohd Yusri Ibrahim \\ Universiti Malaysia Terengganu \\ Terengganu, Malaysia \\ Mat Rahimi Yusof and Mohd Faiz Mohd Yaakob \\ Universiti Utara Malaysia \\ Kedah, Malaysia \\ Zurita Othman \\ Sekolah Menengah Kebangsaan Padang Kemunting \\ Terengganu, Malaysia
}

\begin{abstract}
Teachers' competence has been identified as the most effective contributor to student's achievement. Despite high expectations, diversity of backgrounds and student variations have led to the teaching and learning process to be challenging, causing teachers to be less clear to choose the best teaching method to be implemented in the classroom. This study was conducted to develop a model for determining the best constructs and skills to measure teaching competence. This crosssectional survey study involved 328 teachers of secondary schools at province of Terengganu, Malaysia. The data were collected through questionnaires and analysed using SEM-AMOS by emphasizing four main elements of measurement such loading factor, convergent validity, discriminant validity and composite reliability. This study had successfully developed a measurement model of teacher's teaching competency that contains constructs of (i) communication with students, (ii) teaching strategies, and (iii) classroom management. The findings also identified 21 behavioural skills that teachers can use to improve their teaching competence. It is recommended to all parties whether teachers or educational leaders to utilize this result towards empowering the quality of teacher's teaching, especially in terms of improving the training curriculum, teaching supervision, incentive schemes, promotions and so on.
\end{abstract}

Keywords: teaching and learning; teaching competency; teaching skills; communication skills; teacher communication. 


\section{Introduction}

Studies for decades have summarized the same grasp of good teaching is central to student achievement. These studies agreed that the characters of a teacher such communication skills, teaching skills, teaching planning, skills management, and knowledge on the essence of the curriculum have a direct effect on student learning (Ibrahim \& Amin, 2017). The involvement of teachers in various intellectual enhancement activities has a very positive impact on education climate, as it has a direct correlation with student's performance in the classroom (Yusof et al, 2017). The previous studies also concluded that the effectiveness of a teacher's teaching is directly proportional to the student's achievement (Ibrahim \& Amin, 2017).

Even so, teachers in the classroom are never quiet from various problems. The diversity of student's backgrounds often led them to have multiple variations, thus giving a great challenge to a teacher to ensure that the teaching and learning process went smoothly to ensure that the curriculum's goal was achieved successfully (Ibrahim, 2014). There are many problems faced by teachers in classroom teaching such as how to draw attention to some students, overcrowded classrooms with students, releasing of sounds during teaching and explanation of the lesson, lack of communication and interaction between teachers and students during class, students ignore the instructional, and harassment and abuse by other students (Al-Amarat, 2011).

For newly teachers, they also faced various problems in teaching and learning in the classroom (Megawati \& Astutik, 2019). The problems are however slightly different from those who have served for long. Usually the problems that are faced by new teachers such as teaching work overload, lack of support from other teachers, discipline challenges in classroom and classroom managements (Dias-Lacy \& Guirguis, 2017). The problems faced by these new teachers are usually due to the lack of preparation either during the course of teaching or before starting the service as a new teacher (Darling-Hammond et al, 2016). These weaknesses cause students with backgrounds of high-poverty, high minority schools, non-native for English lesson (Alam, 2019) or at any though conditions such mild mentally retarded children (Widodo et. al, 2019) tend to give big challenges to teachers who are underprepared and inexperienced (DiasLacy \& Guirguis, 2017).

The teachers who teach at higher educational level have different challenges. The biggest challenge is the differences in student's ability, causing teachers in dilemmas to choose the best teaching method that suitable for all student groups (Scager et al, 2016), and also facing psychological stability (Alsalkhi, 2019) due to their teenage ages. This situation causes teachers to face challenges to care for every student's learning, maintaining positive student-teacher relation, keeping all students aboard, maintaining student's enthusiasm, act according to teacher's self-understanding, comply with external expectations, and maintaining student safeties. These challenges cause teachers to be diligent to choose the best teaching method to ensure that no students is left behind, as well as to ensure 
that all students will achieve the educational goals which shave been set for them.

Besides that, other teachers especially those teaching science subjects also faced a lot of challenges in classroom teaching such as (i) lack of resources for teaching and learning, (ii) time management especially to finish the syllabus and achieve lesson objectives, (iii) deficiency in content knowledge, (iv) inability of students to understand the lesson taught, (v) student's discipline in classroom, (vi) lack of student interest in subject matter, and (vii) inability to complete the integrated syllabus of the subjects (Boakye \& Ampiah, 2017). Generally, from all of the above reviews, it is possible to conclude that teachers face a lot of problems and challenges in teaching and learning; and at the same time they still do not have the best model to guide them. Therefore, this study was conducted to develop a model of teacher's teaching competence, by proposing some constructs and skills that can be applied to measure the competence of a teacher in the process of teaching and learning.

\section{Backgrounds}

The teacher's competence was conceptualized as the ability to master the knowledge and skills as well as to have a positive attitude to translate the knowledge into an image so students can understand easily and can be used in everyday life (Sazali et al, 2007). In order to disseminate information to students, teachers should be able to expose the specific and new information to students to enable them to understand easily and clearly, including content, skills and positive attitudes (Good, 1990).

The initial model of effective teaching was developed by Carrol $(1963 ; 1989)$. According to him, effective teacher teaching is influenced by five factors, namely the attitude of teachers, the ability to understand the teaching, the diligence of teachers, the opportunities, and the quality of teaching. Teachers with good teaching competence are teachers who are capable of delivering lessons, concepts or skills that students can easily understand, easy to remember and enjoy (Baez-Hernandez, 2019; Shahril, 2005).

Teachers should also communicate (Berber et. al, 2019) the contents of teaching systematically and structurally (Kallison, 1986), using language that students can easily understand at all levels of ability (Land, 1987), clear explanations and provide appropriate examples (Mayer \& Gallini, 1990), emphasizing the importance of teaching and trying to relate teaching content to the existing experiences of the students (King \& Menke, 1992), using teaching aids to explain the concept of teaching (Hiebert et al, 1991), interact positively with students (Solheim, 2019) and conducting assessments at the end of a lesson (Jusuf et. al, 2019; Shahril, 2005).

Highly competent teachers often teach according to the ability level of the students. If the level of teacher's teaching is too high, slow leaner students will not be able to follow the lesson, as well as they will miss out of the lesson. If the level of teaching is too low, clever learners will not focus on the lessons because 
they will get bored, remain un-attracted and will have no challenges (Shahril, 2005). That is why teachers should choose the best teaching approach, so that they can capture all level of student's ability in a class.

There are different challenges in teaching and learning process for special students. The children with special educational needs learn from their environment with social, emotional and physical stimuli (Jadán-Guerrero et. Al, 2020). Teachers who teach special students are urged to be more creative to attract their interest, play role for example can be implemented to create a fun learning climate. Teachers for example can practicing three hybrid interfaces (Jadán-Guerrero et. al, 2020) such (i) interactive books, combining traditional fairy tales books with mobile devices, where QR codes and NFC tags give life to the stories, (ii) Educational Board Games, where augmented reality markers give an extra information to the players, and (iii) tangible educational resources, which integrate Makey-Makey device and Scratch with fruit, clay, aluminium foil or water to build laboratory. This is a good example done by a teacher how to manipulate situation in order to increase involvement of special needs student in teaching and learning process.

Based on the concepts of teaching competency that was discussed by those previous researchers, it can be concluded that they had focused on three main elements such as teacher's communication skills with students, the choice of effective teaching strategies, and the ability to control the classroom during lessons. For this study, teacher competence was conceptualized as a teacher's teaching skill consisting of three important constructs; (i) how a teacher communicates with students during teaching and learning, (ii) his or her teaching strategies, and (iii) the ability of a teacher to manage or control the classroom. Summary of hypothesis models of teacher's teaching competencies for this study was summarized in Figure 1 below.

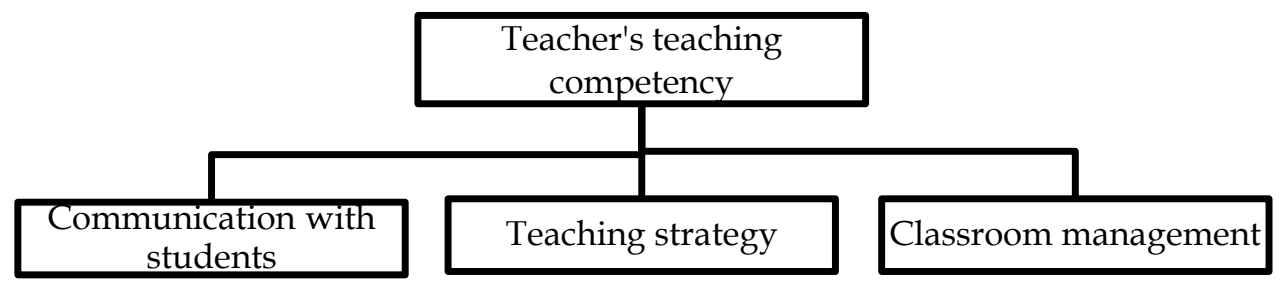

Figure 1: Conceptual model of teaching competency

The main element in teaching competence is teacher's communication skills (Nambi, 2018; Sazali et al, 2007; Good, 1990; Carroll, 1963; Shahril, 2005). For this construct of communication with students, eight skills are suggested. The skills are related to how a teacher interacts with their students in order to guides, helps, convince, motivates and stimulates them to follow the process of teaching and learning effectively. These skills are detailed in Table 1 below. 
Table 1: Construct of communication with students

\begin{tabular}{cl}
\hline No & \multicolumn{1}{c}{ Skills } \\
\hline D1 & Guide the slow leaner students in the lesson. \\
D2 & Guide students to think critically during lesson. \\
D4 & Motivate students who are less interested in completing the assessment or \\
& assignments given. \\
D6 & Convince the students that they can do the exercises or assignments very well. \\
D9 & Guide students to learn effectively. \\
D11 & Ask constructive questions to students during teaching. \\
D12 & Stimulate student creativities ability. \\
D14 & Trying to increase the understanding of a failed student. \\
\hline
\end{tabular}

For the construct of teaching strategies, teachers need good skills to ensure that curriculum goals that are contained in the syllabus are mastered by students. These skills include questioning techniques, answering techniques, choosing of teaching approach and so on (Kallison, 1986; Land, 1987; Mayer \& Gallini, 1990). The skills of the construct of teaching strategy are detailed in Table 2 below.

Table 2: Construct of teaching strategy

\begin{tabular}{cl}
\hline No & \multicolumn{1}{c}{ Skills } \\
\hline D7 & Ability to answers difficult questions asked by students. \\
D10 & Make sure students understand the contents of lesson. \\
D17 & Modify teaching to suit on ability of students. \\
D18 & Implementing a variety of assessment strategies for students. \\
D20 & $\begin{array}{l}\text { Provides alternative explanations or other examples when the student is } \\
\text { confuse. }\end{array}$ \\
D22 & Collaborate with parents to make their child successful in lesson. \\
D23 & Use alternative strategies during teaching. \\
D24 & Provide appropriate challenges for highly capable students in learning. \\
\hline
\end{tabular}

Among the important challenges in teaching and learning is to control classes, especially when teaching in rural schools and minority students. The difference in pupils' backgrounds creates a variety of attitudes and behaviours, thus making the process of controlling the class more challenging. A teacher should ensure that the classroom atmosphere is under his or her control when the learning process is in progress, to ensure that the contents of the lesson can be communicated well (Shahril, 2005). Shown in Table 3 are the classroom management skills that teachers need to master in the classroom. 
Tablel 3: Construct of classroom management

\begin{tabular}{cl}
\hline No & \multicolumn{1}{c}{ Skills } \\
\hline D3 & Controlling student behaviour that interferes with teaching in the classroom. \\
D5 & Recognize or anticipate student behaviour. \\
D8 & Ensuring that effective teaching routines work smoothly. \\
D13 & Ensure that students follow class rules. \\
D15 & Calming down a disruptive or noisy student. \\
D16 & Manage a well teaching for all categories of student abilities in the classroom. \\
D19 & Controlling a small number of students who behave badly from disrupting \\
D21 & Contrall learning in the classroom. \\
\hline
\end{tabular}

All these three constructs and 24 skills for teaching competency are suggested by previous researchers. This study will survey to explore the suitability of all the elements to be accepted as an element in measurement model of teacher's teaching competency. This study was conducted in Malaysia, of course, the findings of this study are according to the suitability of educational climate in Malaysia, as opposed to these literatures of teaching competence that were collected from researches all around the world.

\section{Methods}

\subsection{Designs}

This study used a quantitative method specifically cross-sectional survey design. This design was chosen related to suitability with the large number of research population and big number of respondents who were involved. This study also focused to explore general information about the best behaviours on teaching practices, therefore cross-sectional survey with quantitative approach is the best design for those nature and needs.

\subsection{Participants}

The respondents were 328 teachers of secondary schools in province of Terengganu, Malaysia, which comprise 130 male and 198 female teachers. A total 261 respondents were serving in rural areas, while the rest were in urban schools. A total of 24 respondents had graduated with diploma, 12 of master's degree, and the rest were bachelor's degree holders. Meanwhile, 26.5 per cent taught in the field of languages, 25.9 per cent in sciences and mathematics, 19.5 per cent in vocational and technologies, while the rest taught in humanity. The samples were selected by stratified sampling method, while sample size was determined based on sample size determination technique by Krejcie and Morgan (1970).

\subsection{Measures}

The data were collected through questionnaires using five points of response scales. Respondents were asked to give feedback about their teaching and 
learning practices based on the indicators that starting with 'never' behaviour until 'always' as the most frequently practices. A total of 24 items (Carroll, 1963; Shahril, 2015; Sazali et. Al, 2007) were used to measure teaching competencies that consisted of three constructs, which is eight items for each construct. The reliability coefficients of the constructs ranged 0.84 to 0.88 , while the Alpha value of the whole questionnaire was 0.94 .

\subsection{Analysis}

Data were analysed by structural equation modelling (SEM) that applied AMOS's software. For the development of the measurement model, procedure of confirmatory factor analysis (CFA) approach was conducted. Four main elements of CFA such loading factor, convergent validity, composite reliability and discriminant validity were considered in the determination process. The items, constructs and variables will be consider and accepted as model's elements if the regression weight $(\beta)$ for factors loading was 0.708 and above, the average variance extracted (AVE) for the convergent validity was 0.5 and above, the composite reliability (CR) value was 0.708 and above, and value of AVE's square root was greater than the inter-correlation values between items or between constructs for discriminant validity (Hair, 2012; Chin, 1998; Fornell \& Larcker, 1981). Although the needed value of the factor loading was 0.708 and above, the regression coefficient of more than 0.4 items was still acceptable if the AVE value was achieve, where score was above 0.5 (Hair, 2012).

To determine the fitness between the field data and the proposed model, some fit indexes such as ratio of Khi square, CFI, NFI, PCFI, PNFI and RMSEA were observed. The model was considered as fit once the value of Khi square $<5$, CFI and NFI $>0.90$, PCFI and NFI $>0.50$ and RMSEA $<0.1$ (Meyers et al, 2006). The final model also was considered as fit when at least one of each category of absolute, relative and parsimony indexes were fit.

\section{Results}

The findings show that all constructs of teaching competency are practiced at high level with mean score of 4.0 out of 5.0. This shows that the respondents of the study have good teaching competence in the aspect of communication with students, choosing the best teaching strategies, and controlling the classroom during the teaching and learning process. All variables are also in a normal distribution that allows parametric testing to proceed, while all constructs are also inter-correlated at a strong rate, which support the hypothesis that communication with students, teaching strategy and classroom management are constructs to the variable of teaching competency. The preliminary results are shown in Table 4 below. 
Table 4: Preliminary results

\begin{tabular}{lcccccccc}
\hline \multicolumn{1}{c}{ Constructs } & Mean & Sd & Skew & Kurt & $\mathbf{1}$ & $\mathbf{2}$ & $\mathbf{3}$ & $\mathbf{4}$ \\
\hline $\begin{array}{l}\text { Teaching } \\
\text { competency }\end{array}$ & 4.29 & 0.40 & -0.20 & -0.59 & 1.00 & & & \\
$\begin{array}{l}\text { Communication } \\
\text { with students }\end{array}$ & 4.34 & 0.40 & -0.15 & -0.61 & 0.94 & 1.00 & & \\
$\begin{array}{l}\text { Teaching strategy } \\
\text { Classroom }\end{array}$ & 4.27 & 0.44 & -0.21 & -0.61 & 0.96 & 0.66 & 1.00 & \\
management & 4.33 & 0.41 & -0.34 & -0.45 & 0.93 & 0.61 & 0.64 & 1.00 \\
\hline
\end{tabular}

For model validation, first-time CFA analysis was performed. Figure 2 shows the initial findings where the measurement model reaches an accepted level for certain fitness indexes but instead for some such as CFI and NFI, while CMIN value was also quite high indicating that the model's fitness is relatively low. Some items that have low loading factors needed to be considered to reject such as D1 for construct of communication with students, item of D22 for construct of teaching strategy and D5 for construct of classroom management which had shown in different colours in this initial model. Before that, the AVE and CR values were considered first before the deletion process of these items was carried out.

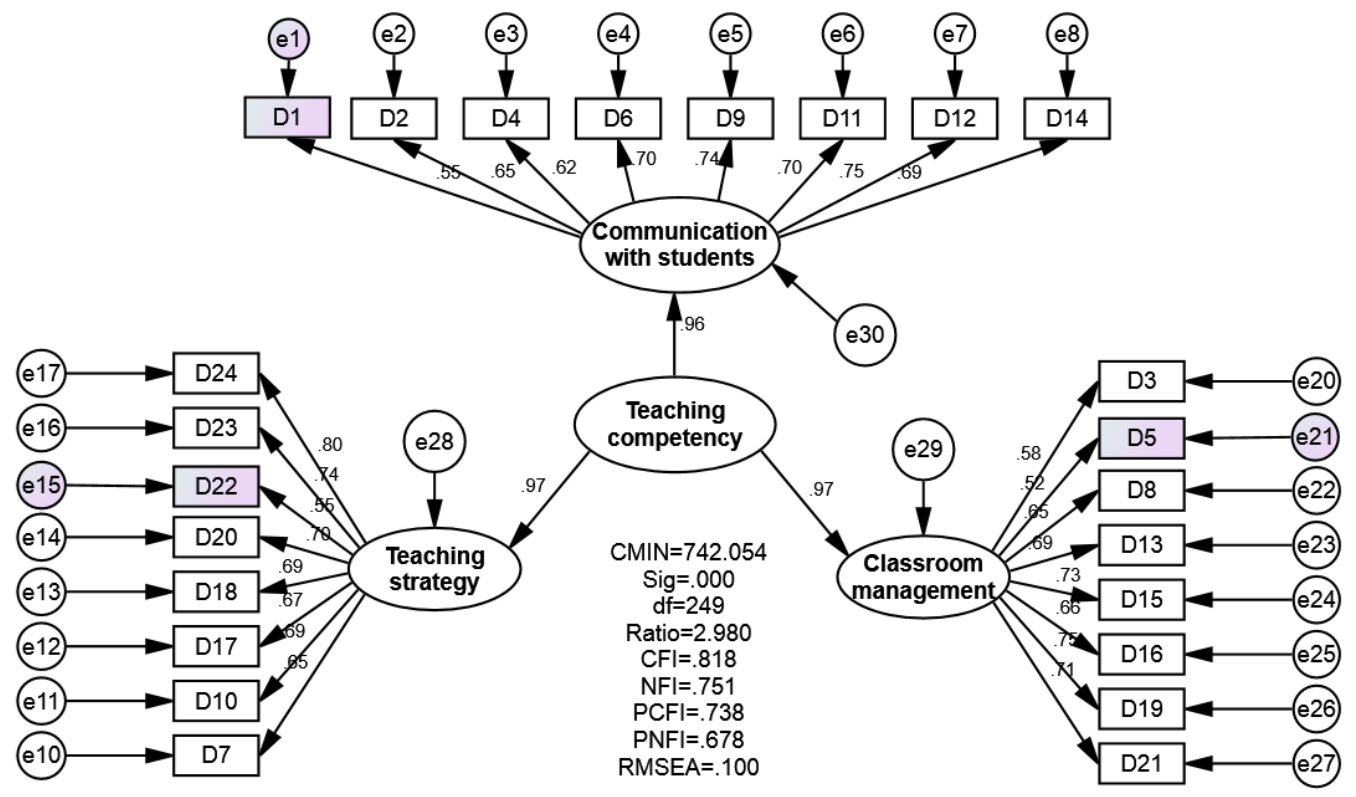

Figure 2: Initial model

The findings in Table 5 below indicated that AVE values do not achieve the required score of 0.5 or above, indicating that the items that were proposed to measure the three constructs did not reach the required level of convergent validity. Some items with a low loading factor that needed to be removed from the model, especially those D1, D5 and D22 were discovered early. 
Table 5: Convergent validity, composite reliability and discriminant validity of initial model

\begin{tabular}{lccc}
\hline Constructs & AVE & CR & $\sqrt{\text { AVE }}$ \\
\hline Teaching competency & 0.94 & 0.98 & 0.97 \\
Communication with & 0.48 & 0.88 & 0.69 \\
students & 0.48 & 0.88 & 0.69 \\
Teaching strategy & 0.46 & 0.87 & 0.68 \\
Classroom & & & \\
management & &
\end{tabular}

For the second time analysis, item of D1 $(\beta=0.55)$ was removed from construct of communication with students, item of D22 $(\beta=0.55)$ was removed from construct of teaching strategy, while item of D5 $(\beta=0.52)$ was removed from the class control's construct. Figure 2 below shows the final model with all the fitness indexes at the acceptant values. The CMIN value for this second model is also smaller than the initial model, indicating that after the removal of those three items, the fitness of the model was increased. Figure 2 below shows all the items and constructs that have been verified to measure the teacher's teaching competency variables. This final model contains three main constructs and 21 items, seven items for each construct.

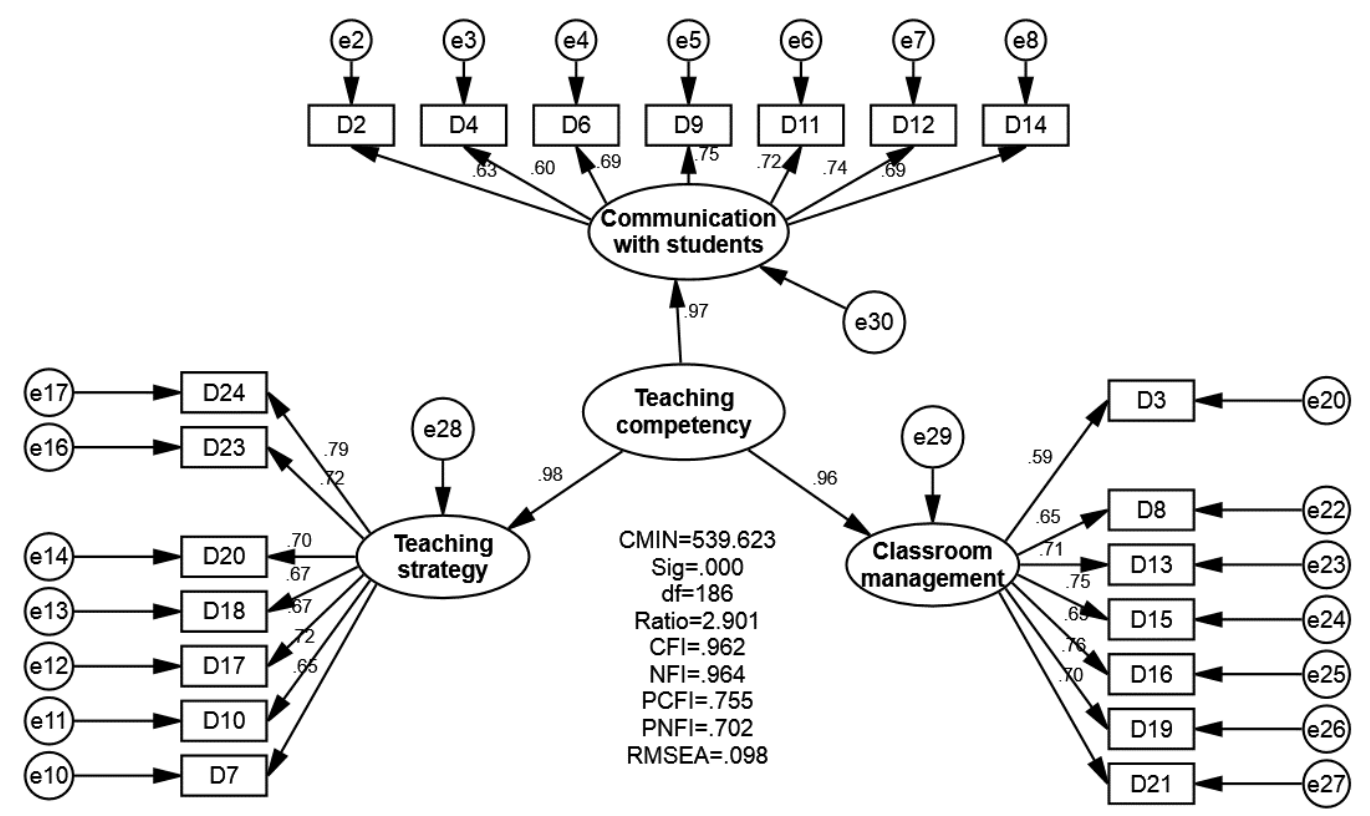

Figure 3: Final model

The findings in Table 6 show that score for measuring convergent validity (AVE) and composite reliability (CR) also achieved the required values, which means the measurement of all constructs in this model fulfilled validity and reliability concerns. The AVE square root values in Table 6 below are also greater than the inter-correlation values between the constructs shown in Table 1. This confirms 
that the measurement of all these constructs reaches the discriminant validity needs.

Table 6: Convergent validity, composite reliability and discriminant validity of initial model

\begin{tabular}{lccc}
\hline Constructs & AVE & CR & $\sqrt{\text { AVE }}$ \\
\hline Teaching competency & 0.94 & 0.98 & 0.97 \\
Communication with & 0.50 & 0.87 & 0.71 \\
students & 0.51 & 0.88 & 0.71 \\
Teaching strategy & 0.50 & 0.87 & 0.71 \\
Classroom & management & & \\
\hline
\end{tabular}

\section{Conclusion and Recommendation}

This study has successfully identified the skills and constructs, as well as successfully developed a teacher's teaching competency measurement model. The findings showed 21 skills and three constructs, namely, communication with pupils, teaching strategies and class managements to attain level of validity, reliability and fitness as a measuring indicator to assess the competence of a teacher's teaching.

The findings of this study are parallel, supporting and enhancing the findings of previous studies which emphasize that teachers need to master the curriculum content well, master the effective teaching pedagogy, be able to manage and control the classes well and have other value added such as mastery of teaching technology, have an interesting approach and understand the psychology of teaching well. All these elements are an effective recipe for good teaching, parallel to the findings of this study.

Hopefully this model can be used as an additional guide by teachers as selfreflection instruments to measure their respective teaching competencies apart. This model is also expected to be base for school leaders for teaching supervision, teaching evaluation, teacher performance evaluation, as well as indicators for any awards for teachers, such as the annual performance awards.

This model can also be used as a guide for teacher training whether a pre-service teacher or a teacher in the service. Responsible parties such as education ministries, state education departments, district education departments and so on can take guidance from this model to improve the existing training curriculum, or develop a new curriculum for teacher training.

This study also successfully identified communication skills as an important element of teaching competence. To ensure that the teaching process works smoothly, teachers need to have good communication skills, especially interpersonal communication with students. Through effective communication, the teacher will effectively convey the content of the lesson to the students, eventually reaching the syllabus. In other words, communication skills are the most important element of teacher's teaching competence. 
To have excellent communication skills, teachers need to get a lot of training either on their own or provided by their superior. School leaders also need to increase the number of courses to enhance teachers' communication skills. As a incentive scheme, teachers with high communication skills should be given incentives whether in the form of promotion, opportunities for outside training, gifts and so on.

Responsible parties such as the educational ministry need to provide training to improve teachers' communication skills. Whether in pre-service or in-service training, communication skills need to be developed in the training syllabus for teachers. These skills need to be adapted to current situations, especially the use of technology and social media, in accordance with the 4th Industrial Revolution (IR 4.0).

To ensure that teachers have adequate communication skills, the teaching supervision process needs to be conducted regularly by school leaders. During supervision, priority should be given to improving teachers' communication skills. Supervisors need to show teachers the best way to communicate with students in teaching and learning. With the support by supervisors, the aim to produce teachers with effective communication skills will be achieved, while improving the quality of teaching in the classroom.

To ensure that teachers' communication skills are at their highest, communication competency tests can also be conducted. Once a year for example, teachers need to sit the test of communication competency, and have to pass at a certain level. This test should be conducted in various ways whether written, oral, project and so on. Teachers who do not meet the required level must take special courses to improve their communication skills. By this way, all teachers will be prepared with the best communication skills at all times, while improving the quality of their teaching in the classroom.

Besides communication skills, teachers also need to master skill of classroom management during teaching and learning. When there are so many students in a class, it can be difficult for a teacher to control them all, especially if there are naughty students, noisy, bullying other students, disobeying teachers, not wanting to do assignments, and so on. To ensure that the learning process runs smoothly and effectively, teachers needs skilful in classroom management, and be good at managing students who interfere with the learning process. Even though students have a variety of backgrounds, teachers need to make sure everyone joining the lesson, principle of no kid left behind should be practicing all the time.

To effectively control the classroom, teachers need to use a variety of approaches when interacting with students. Exercises include persuading a lazy student, giving a gift to a student who has mastered certain skill, smooth penalizing a student for making mistakes, and so on. Teachers need to use a variety of personalities such as affectionate, friendly, assertive and so on to ensure that the 
classroom is always in a conducive state for teaching and learning. In this way, learning can go smoothly and the syllabus goals will be achieved.

For newly teachers, they can learn by senior teachers how to control the classroom well. For beginning teachers, it can be quite difficult to manage multiple students in one class, while those students who have different personalities. In addition taking advices from senior teachers through the mentor-mentee program, newly teachers can also take part in various exercises to enhance their classroom management skills. School leaders also need to provide ongoing in-house training for teachers to improve their classroom management skills, especially for new and inexperienced teachers. Teaching supervision also needs to be ongoing to help teachers improve the quality of classroom control in teaching and learning.

Finally, teachers need to use the best strategies in teaching, depending on the situation and the needs of the students. Students have a variety of potentials and abilities, so teachers need to diversify their strategies to ensure that all their potentials are maximized. Educational leaders also need to provide ongoing training, constructive teaching supervision, attractive incentive schemes, and effective monitoring processes to ensure that teachers practice the best teaching strategies in the classroom.

\section{References}

Alam, M. J. (2019). Critical Views on Implementing English Language Teaching Curriculum with Native \& Non-Native English Language Teachers. International Journal of Learning, Teaching and Educational Research, 18(7):200-212 https://doi.org/10.26803/ijlter.18.7.13

Alsalkhi, M. J. (2019). Spiritual Intelligence and Its Relation with Psychological Stability of a Sample of Students from the College of Arts and Sciences in the University of Petra. International Journal of Learning, Teaching and Educational Research, 18(3): 142163 https://doi.org/10.26803/ijlter.18.3.8

Al-Amarat, M. S. (2011). The classroom problems faced teachers at the public schools in Tafila Province, and proposed solution. International Journal of Educational Sciences, 3(1): 37-47. https:// doi.org/10.1080/09751122.2011.11890007

Baez-Hernandez, R. A. (2019). Impact of Instructional Alignment Workshop on Teachers' Experience with and Beliefs on State Standards. International Journal of Learning, Teaching and Educational Research, 18(1): 104-114 https://doi.org/10.26803/ijlter.18.1.8

Berber, L. C., Kuusisto, E. and Tirri, K. (2019). Teachers' Perceptions of Gratitude in Classroom Interactions: A Case Study from Finland. International Journal of Learning, Teaching and Educational Research, 18(5): 73-88 https://doi.org/10.26803/ijlter.18.5.6

Boakye, C. \& Ampiah, J. G. (2017). Challenges and solutions: The experiences of newly qualified science teachers. SAGE Open, $7(2)$ : $1-10$ https://doi.org/10.1177/2158244017706710

Carroll, J. (1963). A model of school learning. Teacher College Record, 64(8): 723-733.

Chin, W. (1998). The partial least squares approach to structural equation modelling. Modern methods for business research, 295(2): 295-336. 
Darling-Hammond, L., Furger, R. Shields, P. M. \& Sutcher, L. (2016). Adressing California's emerging teacher shortage: An analysis of sources and solutions. Palo Alto, CA: Learning Policy Institute.

Dias-Lacy, S. M. \& Guirguis, R. V. (2017). Challenges for new teachers and ways of coping with them. Journal of Education and Learning, 6(3): 265-272. https://doi.org/10.5539/jel.v6n3p265

Good, T.L., \& Mulryan, C. (1990). Teacher ratings: A call for teacher control and self evaluation. In J. Millman \& L. Darling-Hammond (Eds.), The new handbook of teacher evaluation: Assessing: elementary and secondary school teachers (pp.191215). Newbury Park: CA.

Fornell, C \& Larcker, D. F. (1981). Evaluating structural equation models with unobservable variables and measurement error. Journal of Marketing Research, 18(1): 39-50. https://doi.org/10.2307/3151312

Hair, F., Sarstedt, M., Ringle, M. \& Mena, A. (2012). An assessment of the use of partial least squares structural equation modeling in marketing research. Journal of the academy of marketing science, 40(3): 413-433.

Hiebert, J., Wearne, D., \& Taber, S. (1991). Fourth graders' gradual constructions of decimal fractions during instruction using different physical representations. Elementary School Journal, 91(4), 321-341. https://doi.org/10.1086/461658

Ibrahim, M. Y. (2014). Model of e-leadership, intra-team communication and job satisfaction among school leaders in Malaysia. Mediterranean Journal of Social Sciences, 5(23), 1927-1931. https:// doi.org/10.5901/mjss.2014.v5n23p1927

Ibrahim, M. Y \& Amin, A. (2017). Model kepemimpinan pengajaran pengetua dan kompetensi pengajaran guru. JuKu: Jurnal Kurikulum \& Pengajaran Asia Pasifik, 2(1): 11-25.

Jadán-Guerrero, J., Guevara, C., Lara-Alvarez, P., Sanchez-Gordon, S., Calle-Jimenez, T. Salvador-Ullauri, L., Acosta-Vargas, P. and Bonilla-Jurado, D. (2020). Building Hybrid Interfaces to Increase Interaction with Young Children and Children with Special Needs. Advances in Intelligent Systems and Computing, 959 (2020): 306-314 https://doi.org/10.1007/978-3-030-20040-4_28

Jusuf, R., Sopandi, W., Wulan, A. R. and Sa'ud, U. S. (2019). Strengthening Teacher Competency through ICARE Approach to Improve Literacy Assessment of Science Creative Thinking. International Journal of Learning, Teaching and Educational Research, 18(7): 70-83 https://doi.org/10.26803/ijlter.18.7.5

Kallison, (1986). Effect of lesson organization achievement. American Educational Research Journal, 23(2): 337-347. https://doi.org/10.2307/1162963

King, D. \& Menke, J. (1992). Providing the instructors note: An effective additional to student notetaking. Educational Psychologist, 20(1): 33-39. https://doi.org/10.1207/s15326985ep2001_5

Krejcie, R.V \& Morgan, D.W. (1970). Determining sampel size for research activities. Educational and Psychological Measurement, 30(3), 607-610. https://doi.org/10.1177/001316447003000308

Land, M. L. (1987). Vagueness and clarity. in Dunkin (Ed.), International encyclopedia of teaching and teacher education. N.Y: Pergamon.

Mayer, R.E. \& Gallini, J.K. (1990). When is an illustration worth ten thousand words? Educational Psychology, 82(4): 715-726. https://doi.org/10.1037//00220663.82.4.715

Megawati, F. and Astutik, Y. (2019). Teaching English for the First Time: Frightening or Challenging? International Journal of Learning, Teaching and Educational Research, 18(4): 158-170 https://doi.org/10.26803/ijlter.18.4.9

Nambi, R. (2019). Using Activity Theory to Explore the Possibilities of Integrating ICT in the Training of Literature in English teachers at Makerere University: A Literature 
Review. International Journal of Learning, Teaching and Educational Research, 17(12): 135-148 https://doi.org/10.26803/ijlter.17.12.8

Meyers, L.S, Gamst, G. \& Guarino, A.J. (2006). Aplied multivariate research: Design and interpretation. Sage Publication: London.

Sazali, Y., Rusmini, K. A., Abang, H. A. E. \& Zamri, A. B. (2007). Perkaitan antara kepimpinan instruksional terhadap sekolah berkesan. Jurnal Pengurusan IAB, 2007: 107-119.

Scager, K., Akkerman, S., Pilot, A. \& Wubbels, T. (2016).Teachers dilemmas in challenging student in higher education. Teaching in Higher Education, 22(3): 318335. https:// doi.org/10.1080/13562517.2016.1248392

Shahril, C. H. M. (2005). Amalan pengajaran guru berkesan: Kajian di beberapa sekolah menengah Malaysia. Paper presented at Seminar Penyelidikan Pendidikan Maktab Perguruan Batu Lintang, Batu Lintang.

Solheim, K. (2019). Teachers' Aspirations to Improve their Classroom Interaction. International Journal of Learning, Teaching and Educational Research, 18(6): 147-169 https:// doi.org/10.26803/ijlter.18.6.9

Widodo, S., Azizah, N. and Ikhwanudin, T. (2019). Teaching Mild Mentally Retarded Children using Augmented Reality. International Journal of Learning, Teaching and Educational Research, 18(7): 184-199 https://doi.org/10.26803/ijlter.18.7.12

Yusof, M. R. B., Ibrahim. M. Y. \& Rahim, S.B. A. (2017). Virtual Instructional Leadership and Teachers' Teaching Competency: Mediated by Communication Pattern. International Journal of Academic Research in Business and Social Sciences, 7(8): 96-108 https://doi.org/10.6007/ijarbss/v7-i8/3211 